\title{
Agricultural potential of an industrial sewage sludge in compliance with CONAMA Resolution no. 375/2006 ${ }^{1}$
}

\author{
Potencial agronômico de um lodo de esgoto industrial em \\ atendimento a resolução CONAMA n ${ }^{0}$ 375/2006
}

\author{
Lívia Rodrigues Dias Machado²*; Isabel Cristina de Barros Trannin ${ }^{3}$
}

\begin{abstract}
The agricultural use of sewage sludge is one of the best alternatives to disposal because of its potential as a plant fertilizer and soil conditioner. However, to be safe for agricultural use, the sewage sludge must be evaluated according to its physical, chemical, and biological properties and its origin. In Brazil, NBR 10.004/2004 is the standard that determines the classification of solid waste, and CONAMA Resolution 375/2006 defines the criteria for the agricultural use of sewage sludge. This study evaluated the agricultural potential of an aerobically digested industrial sewage sludge from the Serramar Dairy Cooperative in the city of Guaratinguetá, São Paulo. This sludge was classified as Class IIA waste according to NBR 10.004/2004 and displayed potential for agricultural use by falling within the limits in terms for heavy metals and pathogenic organisms established by Resolution 375/2006 as well as containing high levels of nutrients. To establish the sludge doses allowed for application to crops such as maize (annual) and Eucalyptus sp. (perennial) by the resolution, the amount of nitrogen available in the sludge and the amounts of this nutrient required by these crops were considered. The recommended sewage sludge doses for corn $\left(8 \mathrm{Mg} \mathrm{ha}^{-1}\right)$ and Eucalyptus sp. forestation $\left(6 \mathrm{Mg} \mathrm{ha}^{-1}\right)$ can meet the nitrogen and phosphorus needs of these crops but require supplementation with potassium mineral fertilizer.
\end{abstract}

Key words: Dairy sludge, agricultural recycling, waste valuation

\section{Resumo}

O uso agrícola de lodos de esgoto é uma das melhores alternativas de disposição final, devido ao potencial fertilizante de plantas e de condicionador de solos destes resíduos. No entanto, para que o uso agrícola seja realizado de forma segura, os lodos precisam ser caracterizados quanto as suas propriedades físicas, químicas e biológicas, considerando as especificidades derivadas de sua origem. No Brasil, a classificação de resíduos sólidos é determinada pela norma NBR 10.004/2004 e a Resolução CONAMA 375/2006 define os critérios para uso agrícola de lodos de esgoto. Este estudo teve como objetivo avaliar o potencial agrícola do lodo de esgoto industrial digerido aerobiamente, gerado pela Cooperativa de Laticínios SERRAMAR, do município de Guaratinguetá (SP). De acordo com a NBR 10.004/2004, este lodo foi classificado como Resíduo Classe II-A e apresentou potencial de uso agrícola, por atender aos limites estabelecidos pela Resolução 375/2006 quanto aos teores de metais pesados e presença de organismos patogênicos e por conter elevados teores de nutrientes. Para a definição das

\footnotetext{
1 Parte da Dissertação de mestrado da primeira autora.

2 M.e em Engenharia Civil e Ambiental, Universidade Estadual Paulista “Julio de Mesquita Filho", UNESP, Guaratinguetá, SP, Brasil. E-mail: lips.machado@gmail.com

${ }^{3}$ Dr $^{\mathrm{a}}$ em Agronomia, Prof ${ }^{\mathrm{a}}$, Faculdade de Engenharia de Guaratinguetá, UNESP, Guaratinguetá, SP, Brasil. E-mail: isatrannin@ feg.unesp.br

* Autora para correspondência
} 
doses de aplicação deste lodo em cultivos permitidos, como o milho (anual) e o Eucalyptus sp. (perene), foi considerada a quantidade de nitrogênio disponível no lodo e a dose requerida por estas culturas, conforme descrito na Resolução 375/2006. As doses de lodo de esgoto recomendadas para a cultura do milho $\left(8 \mathrm{Mg} \mathrm{ha}^{-1}\right)$ e para florestamentos de Eucalyptus sp. $\left(6 \mathrm{Mg} \mathrm{ha}^{-1}\right)$ podem atender as exigências nutricionais destas culturas em nitrogênio e fósforo, necessitando de complementação com fertilizante mineral potássico.

Palavras-chave: Lodo de laticínios, reciclagem agrícola, valoração de resíduos

Brazil's National Policy of Solid Waste was created by Law $12.305 / 2010$ and is regulated by Decree 7404 . The principles established by this law include, among others, sustainable development, recognition of reusable solid waste, recycling as an alternative to add value to waste and the systemic view in the management of solid waste, considering all social and environmental variables. The reuse of solid waste stands out among the objectives of this law, as well as environmentally appropriate final waste disposal.

Sewage sludge, or biosolids, is a semisolid waste of either municipal or industrial origin generated by different sewage treatment processes to reduce the sewage's pollution potential and the risks to public health and the environment.

The composition of sewage sludge from municipal sources shows approximately $400 \mathrm{~g} \mathrm{~kg}^{-1}$ organic matter, $40 \mathrm{~g} \mathrm{~kg}^{-1}$ of nitrogen, $20 \mathrm{~g} \mathrm{~kg}^{-1}$ of phosphorus and $4 \mathrm{~g} \mathrm{~kg}^{-1}$ of potassium and other nutrients and elements with toxic potential, in varying proportions (BETTIOL; CAMARGO, 2003). On the other hand, industrial sewage sludge has varying characteristics determined by the specific raw materials, industrial process, and wastewater treatment system used (TRANNIN et al., 2005).

An alternative to the disposal of sewage sludge is its agricultural use as fertilizer, in total or partial replacement of mineral fertilizer and as a soil conditioner (BERTON; NOGUEIRA, 2010). However, to avoid causing environmental, social, and economic impacts, the agricultural use of sewage sludge should be performed safely and properly. To accomplish this, the evaluation of the sludge's physical, chemical, and biological properties is necessary, with consideration of its specific characteristics and compliance with standards and current legislation.

In Brazil, NBR 10.004 of ABNT (2004) establishes that waste may be included in either Class I - Hazardous or Class II - non-hazardous (A - Not inert or B - Inert). CONAMA Resolution 375/2006 (BRASIL, 2006) establishes the criteria and procedures for the agricultural use of sewage sludge generated in sewage treatment and its derivatives. This Resolution defines two sludge classes: class A, for sludge with low concentrations of pathogens, and Class B, for sludge with higher concentrations of pathogens.

This study evaluated the potential for agricultural use of the industrial sewage sludge generated by the Serramar Dairy Cooperative located in Guaratinguetá (SP). This sewage is generated by the milk industrial beneficiation process, and its treatment occurs in the reactor and aerobic sludge digester, with subsequent drying.

For the analysis of the physical, chemical, and biological parameters of this sewage sludge, six samples were collected from the residues delivered to the drying beds on $02 / 13,02 / 15,02 / 19,02 / 27$, $03 / 01$ and $03 / 05$ in 2013. Each sample was collected after nine days of being held in the drying beds. After homogenization, two composite samples were sent to the "Laboratório de Fertilizantes e Resíduos do Instituto Agronômico de Campinas".

The methodologies applied for the analysis were as follows: metals: EPA-SW-846-3051 atomic spectrometry determination according to EPASW-846-6010c; total nitrogen: Kjeldahl method; 
ammonia nitrogen, nitrate and nitrite: steam distillation; organic carbon: dichromate digestion and volumetric determination; moisture and volatile solids: weight loss at $60^{\circ} \mathrm{C}$ and $500^{\circ} \mathrm{C}$, respectively; $\mathrm{pH}$ : determination in 1:10 (residue:water) aqueous extract according to the methods described in Andrade and Abreu (2006). The biological attributes of the sewage sludge were analyzed following the methods described in USEPA part 503 (USEPA, 1993).

The sludge was classified according to NBR 10.004/2004. For the agronomic potential evaluation, we considered the criteria established by CONAMA Resolution 375/2006.Although the Resolution does not apply to sludge from industrial processes, it establishes limits for the agricultural use of these wastes.

According to its chemical, physical and biological attributes, the sewage sludge of Serramar was classified as Class II-A, nonhazardous and not inert waste, according to NBR $10.004 / 2004$ and as Class A waste by the criteria established by Resolution CONAMA 375/2006 (Table 1).

Table 1. Physical, chemical, and biological attributes of sewage sludge from Serramar Dairy Cooperative on a dry matter basis, compared to the typical values found in sewage sludge and the maximum permitted by CONAMA Resolution 375/2006 for agricultural use.

Continue ...

\begin{tabular}{|c|c|c|c|c|}
\hline \multicolumn{5}{|c|}{ Physical and Chemical Attributes } \\
\hline Parameter & Unit & $\begin{array}{l}\text { Sewage sludge } \\
\text { from Serramar }\end{array}$ & $\begin{array}{l}\text { Typical values in } \\
\text { sewage sludge* }\end{array}$ & $\begin{array}{c}\text { Maximum amount } \\
\text { permitted by CONAMA } \\
375 / 2006\end{array}$ \\
\hline pH (1:10residue:water) & --- & 6,8 & Biostabilized $=7,5$ & --- \\
\hline Moisture at $60-65^{\circ} \mathrm{C}$ & $\%\left(\mathrm{~m} \mathrm{~m}^{-1}\right)$ & 33,9 & $>80$ & --- \\
\hline Total solids & $\%\left(\mathrm{~m} \mathrm{~m}^{-1}\right)$ & 64,6 & --- & --- \\
\hline Volatile solids & $\%\left(\mathrm{~m} \mathrm{~m}^{-1}\right)$ & 32,4 & --- & --- \\
\hline Organic carbon & $\mathrm{g} \mathrm{kg}^{-1}$ & 216 & $133-229$ & --- \\
\hline Nitrogen Kjeldahl (Total N) & $\mathrm{g} \mathrm{kg}^{-1}$ & 32,5 & --- & --- \\
\hline Ammoniacal nitrogen & $\mathrm{mg} \mathrm{kg}^{-1}$ & 68,0 & --- & \\
\hline Nitrogen (Nitrate + Nitrite) & $\mathrm{mg} \mathrm{kg}^{-1}$ & 379 & --- & --- \\
\hline Total nitrogen & $\mathrm{g} \mathrm{kg}^{-1}$ & 32,9 & 16 (variable) & --- \\
\hline $\mathrm{C} / \mathrm{N}$ & --- & 6,5 & $11\left(\right.$ releases $\left.\mathrm{NH}_{4}^{+}\right)$ & --- \\
\hline Phosphorus & $\mathrm{g} \mathrm{kg}^{-1}$ & 8,3 & $8(>15=$ high $)$ & --- \\
\hline Potassium & $\mathrm{g} \mathrm{kg}^{-1}$ & 1,9 & $2 \mathrm{~g} \mathrm{~kg}^{-1}(<5=$ low $)$ & --- \\
\hline Calcium & $\mathrm{g} \mathrm{kg}^{-1}$ & 24,3 & $16(<15=$ low $)$ & --- \\
\hline Magnesium & $\mathrm{g} \mathrm{kg}^{-1}$ & 1,8 & $6(<6=$ low $)$ & --- \\
\hline Sulfur & $\mathrm{g} \mathrm{kg}^{-1}$ & 8,2 & $2(<2=$ low $)$ & --- \\
\hline Iron & $\mathrm{mg} \mathrm{kg}^{-1}$ & 5.228 & --- & --- \\
\hline Manganese & $\mathrm{mg} \mathrm{kg}^{-1}$ & 3.858 & --- & --- \\
\hline Zinc & $\mathrm{mg} \mathrm{kg}^{-1}$ & 366 & 900 & 2.800 \\
\hline Copper & $\mathrm{mg} \mathrm{kg}^{-1}$ & 51,2 & 435 & 1.500 \\
\hline Arsenic & $\mathrm{mg} \mathrm{kg}^{-1}$ & 2,3 & --- & 41 \\
\hline Cadmium & $\mathrm{mg} \mathrm{kg}^{-1}$ & 1,4 & 11 & 39 \\
\hline Lead & $\mathrm{mg} \mathrm{kg}^{-1}$ & 11,8 & 360 & 300 \\
\hline Mercury & $\mathrm{mg} \mathrm{kg}^{-1}$ & $<1,0$ & --- & 17 \\
\hline Nickel & $\mathrm{mg} \mathrm{kg}^{-1}$ & 19,3 & 362 & 420 \\
\hline
\end{tabular}




\begin{tabular}{|c|c|c|c|c|}
\hline & & & & ... Continuation \\
\hline Selenium & $\mathrm{mg} \mathrm{kg}^{-1}$ & $<1,0$ & --- & 100 \\
\hline Sodium & $m g \mathrm{~kg}^{-1}$ & 2.092 & --- & --- \\
\hline Barium & $\mathrm{mg} \mathrm{kg}^{-1}$ & 44,6 & --- & 1.300 \\
\hline Chrome & $\mathrm{mg} \mathrm{kg}{ }^{-1}$ & 34,4 & --- & 1.000 \\
\hline Molybdenum & $\mathrm{mg} \mathrm{kg}^{-1}$ & 0,90 & --- & 50 \\
\hline \multicolumn{5}{|c|}{ Biological Attributes } \\
\hline Viable helminth eggs & $\begin{array}{c}<0,25 \text { eggs } \mathrm{g}^{-1} \\
\mathrm{TS}^{1 * *}\end{array}$ & 0 & --- & $<0,25$ eggs g $^{-1} \mathrm{TS}$ \\
\hline Thermotolerant coliforms & $\mathrm{MPN}^{* * *} \mathrm{~g}^{-1} \mathrm{TS}$ & 13,62 & --- & $<10^{3} \mathrm{MPN} \mathrm{g}^{-1} \mathrm{TS}$ \\
\hline Salmonella sp. & MPN $10 \mathrm{~g}^{-1} \mathrm{TS}$ & Absent & --- & Absence $10 \mathrm{~g}^{-1} \mathrm{TS}$ \\
\hline
\end{tabular}

Laboratory tests carried out by the Instituto Agronômico de Campinas - Centro de P\&D de Solos e Recursos Ambientais, accredited by CGCRE, according to ISO/IEC 17025, under number CRL 450. *According to Raij et al. (1997) and Oliveira (2000); ${ }^{* *}$ Total solids; ${ }^{* * *}$ Most Probable Number Test.

Bastos et al. (2009) evaluated the restrictions established by law for the use of sewage sludge and the prohibition of the use of Class B sludge. According to these authors, the use of Class B sludge may be acceptable if accompanied by appropriate measures of health protection with special attention to occupational health, which was subject to higher risks arising from the use of class A and B sludge compared to the risks posed to consumer health. In addition, these authors characterized the standard for the presence of helminth eggs in Class A sludge $\left(<0.25 \mathrm{egg} \mathrm{g}^{-1}\right.$ total solids)as very restrictive and that for Class B sludge ( $<10$ eggs g$^{-1}$ total solids) as permissive considering the high risks to the health of workers.

The Class A residues, although not harmful, may have features such as biodegradability, combustibility, and water solubility. The residue analyzed in this study exhibited high biodegradability in terms of organic $\mathrm{N}$ mineralization, as indicated by a $\mathrm{C} / \mathrm{N}$ ratio of 6.5 . According to Raij et al. (1997), organic compounds with $\mathrm{C} / \mathrm{N}$ ratios less than 25 generally release most $\mathrm{N}$ in the first year of application. The $\mathrm{C} / \mathrm{N}$ ratio found in sewage sludge is typically very low, approximately $5-12$, with a more rapid mineralization of organic $\mathrm{N}$ in $\mathrm{NH}_{4}$

Through the process of nitrification, the $\mathrm{NH}_{4}^{+}$ present in sludge, added to that derived from organic
$\mathrm{N}$, is oxidized to nitrite $\left(\mathrm{NO}_{2}^{-}\right)$and rapidly to nitrate $\left(\mathrm{NO}_{3}^{-}\right)$, which may become a limiting factor for the application of sludge in agricultural soils due to the possibility of leaching and pollution of water resources resulting from the high mobility of $\mathrm{N}$ in the soil (TRANNIN et al., 2008). The low C/N ratio presented by this sludge indicates an advanced decomposition of organic matter, reflecting the high concentration of total nitrogen $\left(32.9 \mathrm{~g} \mathrm{~kg}^{-1}\right)$. The concentrations of $\mathrm{N}, \mathrm{P}$, and $\mathrm{K}$ in sewage sludge are typically found in a ratio of 2:1:0.25, whereas the Serramar sewage sludge presented a ratio of approximately 4:1:0.25, indicating high potential for agricultural use as nitrogen fertilizer.

Although CONAMA Resolution 375/2006 does not set limits on the levels of nitrogen, phosphorus and potassium, the concentrations of these nutrients in the Serramar sewage sludge, except for nitrogen, were very close to those reported by Raij et al. (1997) and Oliveira (2000) and higher than those obtained by Trannin et al. (2008) in sludge originating from the PET resin industry.

The low moisture content of the sludge from Serramar $(33.9 \%)$ may favor the transport of the material long distances, reduce freight costs and enable its agricultural application.

The near-neutral $\mathrm{pH}$ value suggests that this sewage sludge may be corrective when applied to 
very acidic soils, a characteristic of most Brazilian soils, which are highly weathered with low fertility. According to Boeira (2004), there may be an initial increase in $\mathrm{pH}$ in soils treated with sewage sludge containing neutral to alkaline $\mathrm{pH}$, with subsequent acidification of the soil due to degradation reactions of the waste's organic fraction. Araújo et al. (2007) observed that when applied at a proportion of $10 \%$ of the substrate, the addition of sludge originating from the food industry containing low concentrations of $\mathrm{K}$ and high levels of $\mathrm{Ca}, \mathrm{P}$, and $\mathrm{N}$ enhanced the growth of seedlings of tomato, eggplant, chicory and lettuce, whereas higher rates of application increased the $\mathrm{pH}$ of the substrate and the availability of $\mathrm{Ca}$ and decreased the concentration of $\mathrm{K}$, indicating a negative influence on the emergence of these species.

The concentration of $\mathrm{Fe}$ in the studied sludge was lower than the values obtained by Trannin et al. (2005), who reported positive results through the addition of sludge to soil. The Mn content was higher than has been found in other sludge, which favors the application of this residue to crop species with a higher demand for this micronutrient.

The $2.092 \mathrm{mg} \mathrm{kg}^{-1}$ of $\mathrm{Na}$ contained in this sludge can cause the salinization of agricultural soils with repeated applications. However, Trannin et al. (2005) found that the high Na concentration $\left(3,633 \mathrm{mg} \mathrm{kg}^{-1}\right)$ in sewage sludge did not limit the agricultural use of this waste, even when applied for two consecutive years at a dose of $24 \mathrm{Mg}^{-}$ ${ }^{1}$, corresponding to double the nitrogen fertilizer requirement of corn.

The levels of heavy metals in the Serramar sludge were lower than the legal limit and lower than the typical levels for sewage sludge reported by Raij et al. (1997) and Oliveira (2000). A high heavy metal content would limit the agricultural use of sewage sludge because when absorbed by plants, the metals may enter the food chain due to the cumulative effect. According to various studies, the heavy metals found at higher concentrations in sewage sludge are $\mathrm{Cd}, \mathrm{Cr}, \mathrm{Cu}, \mathrm{Ni}, \mathrm{Pb}, \mathrm{Fe}, \mathrm{Co}, \mathrm{Mn}$, $\mathrm{Mo}, \mathrm{Hg}$, Sn and $\mathrm{Zn}$, which in high concentrations in the soil can limit the growth and development of the vegetation as well as accumulate in plants in toxic amounts and inhibit their physiological processes, such as perspiration, respiration, photosynthesis, and the legume nodulation process.

Lobo et al. (2012) found that increasing doses of residential composted sewage sludge increased the dry matter production of non-inoculated soybean plants, whereas in inoculated plants, the production increased up to $26 \mathrm{Mg} \mathrm{ha}^{-1}$ with a decrease at higher doses. Similarly, the number of nodes in inoculated plants increased up to $19 \mathrm{Mg} \mathrm{ha}^{-1}$ with a decrease occurring at higher doses. In non-inoculated plants, there was an increase in the number of nodes up to 7 $\mathrm{Mg} \mathrm{ha}^{-1}$ with a decrease at higher doses, indicating that the sewage sludge had effects on nodulation and biological nitrogen fixation.

Although CONAMA Resolution 375/2006 and the Companhia de Tecnologia de Saneamento Ambiental do Estado de São Paulo - CETESB (P4.230/1999) only establish criteria for the use of domestic sewage sludge, all of the analyzed parameters of the sludge from Serramar met the limitations of these regulations, demonstrating the high potential for agricultural use of this sludge. Several studies have reported advantages to the use of sewage sludge in agriculture when applied to different crops, including corn (TRANNIN et al., 2005), eucalyptus (ROCHA et al., 2013) and legumes (LOBO et al., 2012). In favorable conditions for the mineralization of organic matter, the sludge can release large amounts of mineral $\mathrm{N}$ to the soil in the first days after application (BOEIRA, 2004), as well as improving the aggregation of soil particles, decreasing the soil's density, increasing its porosity, water holding capacity and cation exchange capacity, increasing the amount of organic matter and providing macro and micronutrients (ARAÚJO et al., 2007; TRANNIN et al., 2008). The application of sewage sludge also increased the absorption of nutrients by crops, resulting in higher 
crop yields (TRANNIN et al., 2005).

Each plant species has specific needs and nutritional requirements, and each Brazilian state has specific recommendations for fertilization. As the sludge from Serramar presents no problems related to heavy metals or pathogens and contains high levels of nutrients, particularly nitrogen $(\mathrm{N})$, the criteria adopted for the calculation of sewage sludge doses for application to corn (annual) and Eucalyptus sp. (perennial) were the $\mathrm{N}$ content available in the sewage sludge, the annual $\mathrm{N}$ mineralization fraction of $30 \%$ established for aerobically digested sludge, and the $\mathrm{N}$ doses recommended for these crops in the state of São Paulo (RAIJ et al., 1997) as described in CONAMA Resolution 375/2006 (Table 2). The recommended doses of sludge were calculated with the following equation:

Sludge Dose $\left(\mathrm{Mg} \mathrm{ha}^{-1}\right)=$ recommended $\mathrm{N}$ rate $\left(\mathrm{kg} \mathrm{ha}^{-1}\right) / \mathrm{N}$ available in the sewage sludge $\left(\mathrm{kg} \mathrm{Mg}^{-}\right.$ 1),

Table 2. Doses of $\mathrm{N}_{2} \mathrm{P}_{2} \mathrm{O}_{5}$ and $\mathrm{K}_{2} \mathrm{O}$ recommended for mineral fertilization of corn and Eucalyptus sp. forest in São Paulo state and quantities supplied by sewage sludge from Serramar Dairy Cooperative. 5

\begin{tabular}{|c|c|c|c|c|c|c|}
\hline \multirow{2}{*}{ Crop } & \multicolumn{3}{|c|}{ Sewage sludge $^{*}$} & \multicolumn{3}{|c|}{ Mineral Fertilizer* } \\
\hline & $\mathrm{N}$ & $\mathrm{P}_{2} \mathrm{O}_{5}$ & $\mathrm{~K}_{2} \mathrm{O}$ & $\mathrm{N}$ & $\mathrm{P}_{2} \mathrm{O}_{5}$ & $\mathrm{~K}_{2} \mathrm{O}$ \\
\hline & \multicolumn{6}{|c|}{$-{ }_{2}^{2}$} \\
\hline Corn - grain and silage & 80 & 76 & 18 & 80 & 80 & 70 \\
\hline Eucalyptus $\mathrm{sp} .-$ homogeneous forestation & 60 & 114 & 14 & 60 & 120 & 80 \\
\hline
\end{tabular}

*Average quantities of $\mathrm{N}_{2} \mathrm{P}_{2} \mathrm{O}_{5}$ and $\mathrm{K}_{2} \mathrm{O}$ provided by the Serramar sewage sludge on a dry matter basis, considering rates of $30 \%$ of nitrogen (CONAMA 375/2006), $50 \%$ of $\mathrm{P}_{2} \mathrm{O}_{5}$ and $100 \%$ of $\mathrm{K}_{2} \mathrm{O}$ available per year, respectively (SANEPAR, 1997). For the Eucalyptus sp. (perennial species), a rate of $100 \%$ availability of $\mathrm{P}_{2} \mathrm{O}_{5}$ was considered;

${ }^{* *}$ Raij et al. (1997).

To obtain a productivity of $4.6 \mathrm{t} \mathrm{ha}^{-1}$, the recommended mineral fertilizer application rate for corn is $80 \mathrm{~kg} \mathrm{ha}^{-1} \mathrm{~N}, 80 \mathrm{~kg} \mathrm{ha}^{-1}$ of $\mathrm{P}_{2} \mathrm{O}_{5}$ and $70 \mathrm{~kg}$ ha ${ }^{-1} \mathrm{~K}_{2} \mathrm{O}$, including planting: $20 \mathrm{~kg} \mathrm{ha}^{-1} \mathrm{~N} ; 80 \mathrm{~kg}$ ha $^{-1} \mathrm{P}_{2} \mathrm{O}_{5}$ and $50 \mathrm{~kg} \mathrm{ha}^{-1} \mathrm{~K}_{2} \mathrm{O}$ and coverage: $60 \mathrm{~kg}$ ha $^{-1} \mathrm{~N}$ and $20 \mathrm{~kg} \mathrm{ha}^{-1} \mathrm{~K}_{2} \mathrm{O}$ (RAIJ et al., 1997). Based on the recommended $\mathrm{N}$ dose for corn $\left(80 \mathrm{~kg} \mathrm{ha}^{-1}\right)$ and considering the MFN rate of $30 \%$, the dose of Serramar sewage sludge to be applied is $8 \mathrm{Mg} \mathrm{ha}^{-1}$. It was found that this sludge dose would be sufficient to meet the $\mathrm{N}$ and $\mathrm{P}_{2} \mathrm{O}_{5}$ nutritional requirements of corn, even considering the $\mathrm{P}_{2} \mathrm{O}_{5}$ mineralization rate of $50 \%$ in the first year of application to soil, as recommended by the SANEPAR (1997), whereas a mineral supplementation of $52 \mathrm{~kg} \mathrm{ha}^{-1} \mathrm{~K}_{2} \mathrm{O}$ would be required.

For plantations of Eucalyptus sp. in a homogeneous forestation pattern on soils with 
low organic matter content $\left(0-15 \mathrm{~g} \mathrm{dm}^{-3}\right)$, an application dose of $60 \mathrm{~kg} \mathrm{ha}^{-1} \mathrm{~N}$ is recommended. For phosphate fertilizers in soils with $\mathrm{P}$ resin $0-2$ $\mathrm{mg} \mathrm{dm}{ }^{-3}$ and clay content $>350 \mathrm{~g} \mathrm{~kg}^{-1}, 120 \mathrm{~kg} \mathrm{ha}^{-1}$ $\mathrm{P}_{2} \mathrm{O}_{5}$ should be added to the soil, and for potassium fertilization in soils with exchangeable $\mathrm{K}\left(\mathrm{k}^{+}\right)$ of 0-0.7 mmol dm $\mathrm{m}^{-3}$ and clay content $>350 \mathrm{~g} \mathrm{~kg}^{-}$ ${ }^{1}, 80 \mathrm{~kg} \mathrm{ha}^{-1} \mathrm{~K}_{2} \mathrm{O}$ should be applied. Based on the $\mathrm{N}$ dose for Eucalyptus sp. forest $\left(60 \mathrm{~kg} \mathrm{ha}^{-1}\right)$ and considering the MFN rate of $30 \%$, the Serramar sludge dose to be applied is $6 \mathrm{Mg} \mathrm{ha}^{-1}$. Also, in this case it was observed that the recommended sludge dose can meet the nutritional requirement for $\mathrm{N}$ and practically all of the requirement for $\mathrm{P}_{2} \mathrm{O}_{5}$, requiring mineral supplementation of $66 \mathrm{~kg} \mathrm{ha}^{-1} \mathrm{~K}_{2} \mathrm{O}$.

Due to its low concentration of potassium, for the agricultural use of this sludge, the mineral supplementation of this nutrient is essential and has been recommended in other studies. Although the agricultural use of sewage sludge can improve plant growth and thereby increase crop productivity due to the improved supply of nutrients, these nutrients do not always occur in balanced concentrations in sludge, and the crops cannot respond positively to its application if there is no mineral supplementation of potassium.

The results of this study indicated that the sewage sludge from the Serramar Cooperative Dairy has high potential for agricultural use as a source of organic matter and nutrients, primarily nitrogen and phosphorus, for annual and perennial crops. However, it is necessary to observe the nutritional requirements of each plant species so that the definition of sludge application rates and mineral supplementation is conducted in an environmentally safe and economically viable manner and to meet the criteria established by Resolution CONAMA $375 / 2006$. Although the use of this sludge as fertilizer does not totally replace mineral fertilizers, it can reduce the need for application of mineral fertilizers and consequently agricultural costs as well as the environmental impact of sludge disposal.

\section{References}

ANDRADE, J. C.; ABREU, M. F. (Ed.) Análise química de resíduos sólidos para monitoramento e estudos agroambientais. Campinas: Editora IAC, 2006. 178 p.

ARAÚJO, F. F.; TIRITAN, C. S.; IAROSSI, F. R. Reciclagem de lodo industrial, classe II, como substrato para produção de mudas. Colloquium Agrariae, Presidente Prudente, v. 3, n. 1, p. 25-34, 2007.

ASSOCIAÇÃO BRASILEIRA DE NORMAS TÉCNICAS - ABNT. NBR 10. 004: classificação de Resíduos. Rio de Janeiro, 2004. p. 71.

BASTOS, R. K. X.; BEVILACQUA, P. D.; DIAS, G. M. F.; BARONY, F. J. A. Análise crítica da legislação brasileira para uso agrícola de lodos de esgotos na perspectiva da avaliação quantitativa de risco microbiológico. Revista AIDIS de Ingeniería y Ciencias Ambientales: Investigación, Desarrollo y Práctica, Coyoacán, v. 2, n. 1, p. 143-159, 2009.

BERTON, R. S.; NOGUEIRA, T. A. R. Uso de lodo de esgoto na agricultura. In: COSCIONE, A. R.; NOGUEIRA, T. A. R.; PIRES, A. M. M. Uso agrícola de lodo de esgoto: avaliação após a resolução $\mathrm{n}^{\circ} 375$ do CONAMA. Botucatu: FEPAF, 2010. cap. 2, p. 31-50.

BETTIOL, W.; CAMARGO, O. A. Lodo de esgoto na agricultura: potencial de uso e problemas. Jaguariúna: Instituto de Educação Tecnológica - IETEC, 2003. Disponível em: $<$ http://www.ietec.com.br $>$. Acesso em: 12 maio 2014.

BOEIRA, R. C. Uso de lodo de esgoto como fertilizante orgânico: disponibilização de nitrogênio em solo tropical. Jaguariúna: EMBRAPA, 2004. 3 p. (Comunicado técnico, n. 12 ).

BRASIL. CONSELHO NACIONAL DE MEIO AMBIENTE - CONAMA. Resolução no 375 de 29 de agosto de 2006. Define critérios e procedimentos, para o uso agrícola de lodos de esgoto gerados em estações de tratamento de esgoto sanitário e seus produtos derivados, e dá outras providências. Diário Oficial [da] União, Brasília: Ministério do Meio Ambiente, 2006, Seção 1, p. 141-146. Disponível em: <http://www.mma.gov.br/ port/conama/res/res06/res37506.pdf>. Acesso em: 28 set. 2013.

COMPANHIA DE SANEAMENTO DO PARANÁ SANEPAR. Manual técnico para utilização agrícola do lodo de esgoto no Paraná. ANDREOLI, C. V.; FERNANDES, F. (Coord.). Curitiba: [s.n.], 1997. 96 p.

LOBO, T. F.; FILHO, H. G.; NOGUEIRA, E. J. B.; ALMEIDA, L. S.; NOMIYAMA JUNIOR, N. Crescimento e fixação biológica do nitrogênio em soja 
cultivada com doses de lodo de esgoto compostado. Semina: Ciências Agrárias, Londrina, v. 33, n. 4, p. 1333-1342, 2012.

OLIVEIRA, F. C. Disposição de lodo de esgoto e composto de lixo urbano em Latossolo Vermelho Amarelo cultivado com cana-de-açúcar. 2000. Tese (Doutorado em Agronomia) - Escola Superior de Agricultura Luiz de Queiroz, Universidade de São Paulo, Piracicaba.

RAIJ, B. V.; CANTARELA, H.; GUAGGIO, J. A.; FURLANI, A. M. C. Recomendações de adubação e calagem para o estado de São Paulo. 2. ed. Campinas: Instituto Agronômico e Fundação IAC, 1997. 285 p. (Boletim técnico, 100).

ROCHA, J. H. T.; BACKES, C.; DIOGO, F. A. Composto de lodo de esgoto como substrato para mudas de eucalipto. Pesquisa Florestal Brasileira, Colombo, v. 33, n. 73, p. 27-35, 2013.
TRANNIN, I. C. B.; SIQUEIRA, J. O.; MOREIRA, F. M. S. Atributos químicos e físicos de um solo tratado com biossólido industrial e cultivado com milho. Revista Brasileira de Engenharia Agrícola e Ambiental, Campina Grande, v. 12, n. 3, p. 223-230, 2008.

TRANNIN, I. C. B.; SIQUEIRA, J. O.; MOREIRA, F. M. $\mathrm{S}$. Avaliação agronômica de um biossólido industrial para a cultura do milho. Pesquisa Agropecuária Brasileira, Brasília, v. 40, n. 3, p. 261-269, 2005.

UNITED STATES ENVIRONMENTAL PROTECTION AGENCY - USEPA. The Standards for the use or disposal of sewage sludge, title 40 of the code of federal regulations, Part 503. Washington: [s.n.], 1993. 